\title{
三十年来长江中下游湖泊富营养化状况变迁及其影响因素
}

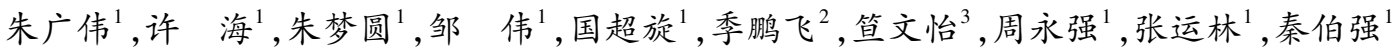 \\ (1: 中国科学院南京地理与湖泊研究所湖泊与环境国家重点实验室太湖湖泊生态系统研究站, 南京 210008) \\ (2: 江南大学环境与土木工程学院,无锡 214122) \\ (3: 西华师范大学环境科学与工程学院,南充 637002)
}

摘 要: 为弄清长江中下游通江/历史通江湖泊富营养化现状、成因及修复策略, 对该区域 27 个大型湖泊和水库开展了 4 个季度的水质调查, 并结合部分湖泊 1988-1992 年及 2008 年两个时段富营养化调查成果, 分析近 30 年来长江中下游地 区大型湖泊富营养化关键指标变化的特征及其驱动因素. 结果表明, 目前该区域绝大多数湖泊处于富营养水平, 较 $1980 \mathrm{~s}$ 有明显加重, 浮游植物叶绿素 a 及总磷是最主要的营养状态指数贡献因子; 湖泊的富营养化状况与湖泊的江湖连通状况、 换水周期等流动性状况、渔业养殖及管理、流域纳污、治理强度等人类活动方式和强度密切相关; 与历史调查结果相比, 氮、磷的增幅相对较小, 而有机质污染程度明显加重、浮游植物叶绿素 a 浓度大幅增高, 表明营养盐之外的其他因素, 如水 文节律的变化、江湖阻隔、不合理的渔业养殖活动等, 对该区域湖泊的富营养化问题加剧、浮游植物生产力增高起到更为 重要的作用. 因此, 从治理途径和策略上来看,增加湖泊的流通性、恢复部分湖泊的自然水文波动节律、优化湖泊渔业管 理、提升湖泊流域营养盐的有效截留能力、实施湖泊生态修复工程是控制长江中下游湖泊富营养化、提升区域湖泊生态 质量的关键.

关键词: 长江中下游平原;浅水湖泊;富营养化;江湖阻隔;生态渔业;网围养殖

\section{Changing characteristics and driving factors of trophic state of lakes in the middle and lower reaches of Yangtze River in the past 30 years}

ZHU Guangwei ${ }^{1}$, XU Hai ${ }^{1}$, ZHU Mengyuan ${ }^{1}$, ZOU Wei ${ }^{1}$, GUO Chaoxuan ${ }^{1}$, JI Pengfei ${ }^{2}$, DA Wenyi ${ }^{3}$, ZHOU Yongqiang ${ }^{1}$, ZHANG Yunlin ${ }^{1} \&$ QIN Boqiang ${ }^{1}$

(1: Taihu Laboratory for Lake Ecosystem Research, State Key Laboratory of Lake Science and Environment, Nanjing Institute of Geography and Limnology, Chinese Academy of Sciences, Nanjing 210008, P.R. China)

(2: School of Environment and Civil Engineering, Jiangnan University, Wuxi 214122, P.R.China)

(3: China West Normal University, College of Environmental Science and Engineering, Nanchong 637002, P.R.China)

Abstract: To understand the current eutrophication status, main drivers of eutrophication and restoration strategy of Yangtze-connected or Yangtze-isolated lakes ( historically connected to the Yangtze River but isolated by artificial dikes currently), the trophic parameters and main water quality variables were surveyed seasonally in 27 large lakes and reservoirs of this region during 2017 to 2018. In addition, the temporal eutrophication dynamics and associated driving mechanisms of these lakes over the past 30 years were analyzed based on the historical data of these lakes (investigated during 1988 to 1992 and 2008). Our results showed that most of the lakes in the middle and lower reaches of Yangtze River were eutrophic now, and significantly worse than the status of 1988 to 1992 , mainly contributed by chlorophyll-a of phytoplankton and total phosphorus. Human activities, including changes of water retention time ( primarily depend on the lake-Yangtze connection condition), fishery activities, catchment pollution condition, and lake restoration are decisive factors in shaping the eutrophication status of these lakes. Comparing with the historical records, phytoplankton chlorophyll-a and associated organic matter concentrations are increased drastically, while nutrients (e.g. , total phosphorus and nitrogen) experienced relatively small increase, yet. Therefore, it is suggested that the non-nutrients factors

* 中国科学院战略性先导科技专项 (A 类) (XDA23040201)、中国科学院重点部署项目 (ZDRW-ZS-2017-3-4) 和国家 自然科学基金项目 (41671494,41830757) 联合资助. 2019-03-09 收稿; 2019-04-18 收修改稿. 朱广伟( 1972 ), 男,博士,研究员;E-mail: gwzhu@ niglas.ac.cn. 
were the major causes which strengthen the eutrophication risk. From the perspective of restoration strategies of lakes in the middle and lower reaches of Yangtze River, it is crucial that rebuild the hydrological connectivity, restore natural water level fluctuation, optimize the fishery management and enhance the catchment nutrient abatement ability and applying the in-lake restoration engineering.

Keywords: Flood plain of Yangtze River; shallow lake; eutrophication; river-lake isolation; ecological fishery; enclosure aquaculture

湖泊是地表极其珍贵的水资源, 特别是淡水湖泊, 由于其能够为沿湖工农业发展和生活提供稳定而清 洁的水资源和水产品, 往往成为人类活动与发展的热点区域. 因此, 湖泊的生态过程机制及其保护利用对策 一直是环境科学、生态科学研究主题之一 ${ }^{[1-3]}$. 我国湖泊资源尤为珍贵且受损较重. 1950s 末 $-1980 \mathrm{~s}$ 中期完 成的第一轮湖泊资源调查表明, 我国面积大于 $1 \mathrm{~km}^{2}$ 湖泊数量为 2759 个, 总面积 $91019.63 \mathrm{~km}^{2[4]}$; 但到了 2007-2009 年第二轮湖泊资源调查时, 面积大于 $1 \mathrm{~km}^{2}$ 的湖泊数量减少为 2693 个, 总面积下降为 81414.6 $\mathrm{km}^{2}$, 湖泊面积萎缩了 $1 / 10^{[5]}$. 此外, 湖泊富营养化以及环湖地带过度开发等造成的生态退化问题也非常突 出 $^{[6]}$. 因此,湖泊保护长期成为我国水环境保护的主题之一 ${ }^{[7-8]}$, 也是近年来我国 “山水林田湖草” 生态文明 建设的重要内容. 研究我国湖泊生态环境演变规律及其驱动机制对支撑我国水环境保护具有重要作用.

长江中下游地区是我国淡水湖泊资源最为集中的区域, 拥有面积大于 $1 \mathrm{~km}^{2}$ 的湖泊 651 个, 大于 100 $\mathrm{km}^{2}$ 的湖泊 18 个 ${ }^{[9]}$. 据 $1980 \mathrm{~s}$ 调查资料估算大于 $1 \mathrm{~km}^{2}$ 的湖泊总面积 $16558 \mathrm{~km}^{2}$, 占我国淡水湖泊总面积的 $60 \%$ 以上 ${ }^{[4]}$. 同时这一地区也是我国湖泊富营养化问题最普遍的地区 ${ }^{[9]}$. 自 $1980 \mathrm{~s}$ 以来, 长江中下游地区一 直是我国湖泊开发与保护的热点区域, 人类活动强度大, 湖泊保护与开发的矛盾大. 太湖、巢湖、武昌东湖等 湖泊的富营养化问题与生态修复成为我国湖泊治理的经典案例 ${ }^{[10-12]}$. 然而, 由于营养本底高、经济发展旺 盛、流域水文格局变化大等多重因素, 该区域湖泊富营养化的问题仍普遍存在 ${ }^{[13-14]}$, 湖泊富营养化治理和生 态保护的思路及效果仍有待重新考量 ${ }^{[15-16]}$.

长江中下游地区湖泊的富营养化问题久治不愈的根源, 除了营养盐负荷增高之外, 是否还存在其他的 驱动因素? 在实施长江经济带 “共抓大保护” 战略上, 除了营养盐削减之外是否还有其他抓手? 针对这些科 学问题,本研究基于 2017-2018 年对长江中下游地区 27 个典型湖泊和水库的水质调查数据, 试图揭示该地 区湖泊富营养化问题的现状和特征, 并对比典型湖泊 1988-1992 年实施的第一轮湖泊富营养化调查、2008 年实施的第二轮湖泊资源调查的结果, 深人分析 30 年来该区域湖泊富营养化问题变化的特征, 揭示其中的 关键驱动因素,为我国湖泊富营养化治理提供科学依据.

\section{1 材料与方法}

\section{1 调查水体空间分布及水文形态特征}

2018 年 4-5 月及 7 月, 从荆州长湖至上海淀山湖, 选取不同类型的湖泊和水库共计 27 个(图 1), 包括 鄱阳湖、洞庭湖、太湖、巢湖区域内的 4 大淡水湖, 安徽安庆地区的花凉亭水库 (又称花亭湖)、黄山地区的陈 庄水库 (又称太平湖) 及鄱阳湖修水上的柘林水库 (又称柘林湖) 等域内几个主要水库, 武昌东湖、岳阳南 湖、黄石磁湖 3 个城市湖泊, 以及其他多个面积超过 $100 \mathrm{~km}^{2}$ 的湖泊.

以《中国湖泊志》中 1988-1992 年中国主要湖泊水质调查资料统计结果 ${ }^{[4]}$, 结合各省湖泊分论中所列 的湖泊基本属性,本次调查水体的基本属性如表 1 .

从表中可知, 不包括水库, 所调查的 24 个面积大于 $1 \mathrm{~km}^{2}$ 的湖泊总面积为 $11389.27 \mathrm{~km}^{2}$, 占该区域所有 大于 $1 \mathrm{~km}^{2}$ 湖泊总面积的 $69 \%$.

此外, 根据《中国湖泊志》中所列的我国主要湖泊水质数据 (主要是 $1988-1992$ 年调查资料 ${ }^{[4]}$, 以及中 国科学院南京地理与湖泊研究所 2007-2009 年第二轮中国湖泊水量水质基础调查资料,获得了 2008 年春 季 (3-4 月)、夏季 ( $7-8$ 月) 调查的龙感湖、鄱阳湖、梁子湖、菜子湖、滆湖、洪湖、武山湖、黄大湖、长湖、洞 庭湖、阳澄湖、淀山湖、巢湖、磁湖、武昌东湖、太湖 16 个湖泊的总氮 $(T N)$ 、总磷 ( TP) 、透明度 (SD)、高锰酸 盐指数 $\left(\mathrm{COD}_{\mathrm{Mn}}\right)$ 、浮游植物叶绿素 $\mathrm{a}(\mathrm{Chl} . \mathrm{a})$, 并根据中国科学院太湖湖泊生态系统研究站的数据库, 获得了 太湖 2008 年 4 月、 7 月及 2017 年 10 月、2018 年 1 月、 4 月、 7 月北部太湖 14 个监测点的上述各参数状况. 


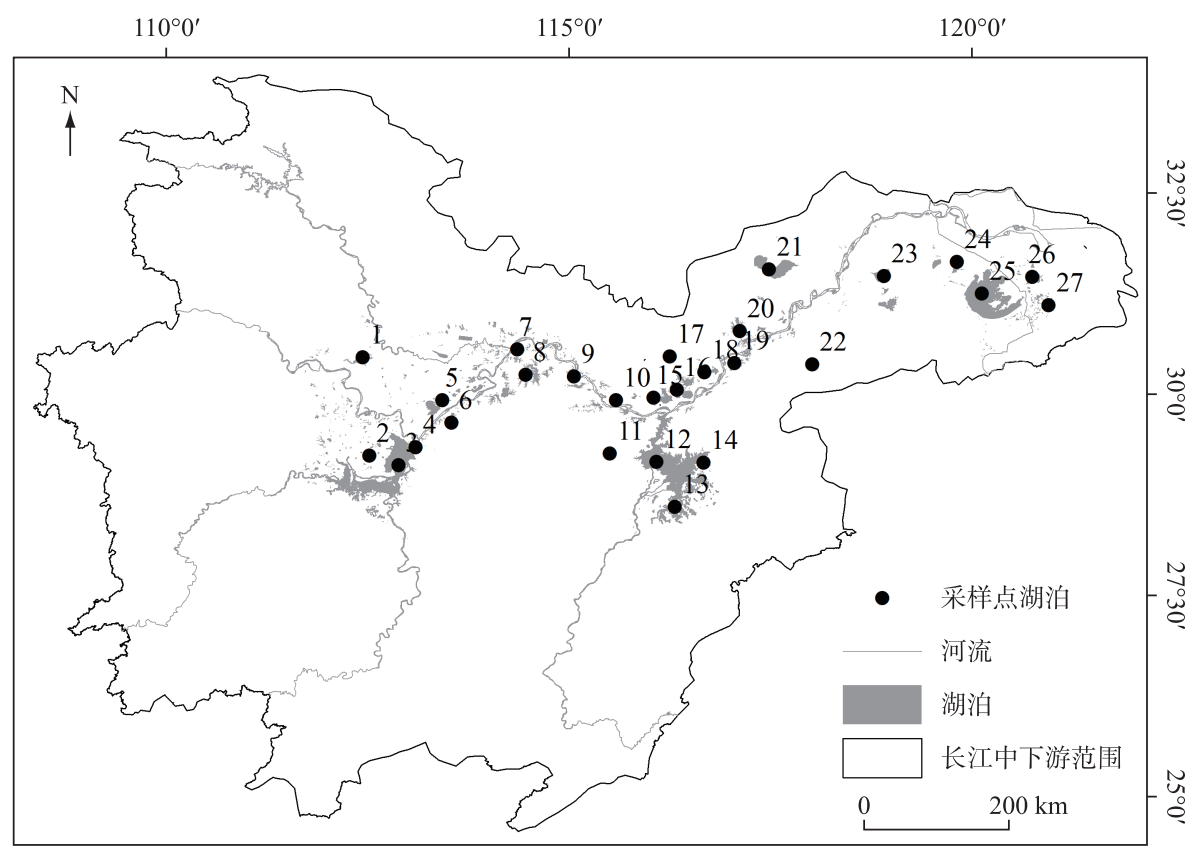

图 1 长江中下游调查湖泊和水库位置 (1.长湖,2.大通湖,3.洞庭湖,4.岳阳南湖,5.洪湖,6. 黄盖湖, 7.武昌东湖,8.梁子湖,9.磁湖, 10.武山湖, 11. 柘林水库, 12.鄱阳湖, 13.军山湖, 14.珠湖, 15. 龙感湖, 16. 黄大湖, 17. 花凉亭水库, 18. 武昌湖, 19.升金湖,20.菜子湖,21.巢湖, 22. 陈庄水库,23. 石臼湖,24.滆湖,25.太湖,26.阳澄湖,27.淀山湖;序号与表 1 中相同)

Fig.1 Locations of the investigated lakes and reservoirs in middle and lower reaches of Yangtze River

\section{2 样品采集与分析方法}

本次调查主要在 2018 年 4-5 月及 7 月开展了 2 次,分别代表春季和夏季水质特征,也是该区域湖泊富 营养化主要发生期. 此外, 在 2017 年 10 月及 2018 年 1 月, 先对其中的鄱阳湖、洞庭湖、太湖、巢湖、洪湖、滆 湖、柘林水库 7 个水体进行了前期调查, 以反映主要湖泊秋季和冬季的水质特点. 因湖泊面积不同, 各个湖 泊调查的点位数量不同, 鄱阳湖、洞庭湖、太湖、巢湖的调查点位数分别为 9 个、14 个、14 个、13 个, 所有 27 个水体共布设监测点位 157 个. 柘林水库、花凉亭水库、陈村水库主要调查了水库靠近大坝 $10 \mathrm{~km}$ 以内的典 型区域,采样深度为水下 $1 \mathrm{~m}$ 左右.

现场用美国 Speedtech 公司的 SM-5A 测深仪先测定样点的水深 (WD), 观察记录水草分布、设施渔业、水 色、蓝藻水华状况等相关信息, 采用 YSI 公司的 EXO 多参数水质仪测定水温 (WT)、电导率 (Cond)、溶解氧 (DO) 等参数. 采集水下 $0.5 \sim 1.0 \mathrm{~m}$ 深度水样, 现场用手动㬌将定量体积的水样 (100 1000 ml 不等, 因水质 情况而定) 过 Whatman GF/F 滤膜 (滤膜孔径 $0.7 \mu \mathrm{m}$ ) 2 张. 2 张滤膜立即分别用铝䈃包裹后冷藏,带回实验 室用于水体 Chl.a 及悬浮颗粒物 (SS) 指标的测定. 分装滤前样 $100 \mathrm{ml}$ 左右冷藏保存, 用于 $\mathrm{TN} 、 \mathrm{TP} 、 \mathrm{COD}_{\mathrm{Mn}}$ 测 定. 分装滤后样 $100 \mathrm{ml}$ 左右冷藏保存, 用于溶解性总氮 (DTN)、溶解性总磷 (DTP)、氨氮 $\left(\mathrm{NH}_{3}-\mathrm{N}\right)$ 、硝态氮 $\left(\mathrm{NO}_{3}^{-}-\mathrm{N}\right)$ 、亚硝态氮 $\left(\mathrm{NO}_{2}^{-}-\mathrm{N}\right)$ 、磷酸根磷 $(\mathrm{DRP})$ 、溶解性有机碳 $(\mathrm{DOC})$ 等指标测定.

TN 、DTN、TP、DTP 浓度采用碱性过硫酸钾消解、分光光度法测定 ${ }^{[19]}$, 其中氮浓度的测定波长为 $210 \mathrm{~nm}$, 磷浓度的测定波长为 $700 \mathrm{~nm}$, 测定仪器为岛津 UV-2600 型分光光度计. Chl.a 浓度采用热乙醇提取、分光光 度法测定 ${ }^{[20]}$. $\mathrm{COD}_{\mathrm{Mn}}$ 的测定采用酸性水浴、高锰酸钾氧化、草酸钠还原滴定法 (GB 11892-1989). SS 浓度采 用 $103 \sim 105^{\circ} \mathrm{C}$ 烘干法测定. $\mathrm{NH}_{3}-\mathrm{N} 、 \mathrm{NO}_{3}^{-}-\mathrm{N} 、 \mathrm{NO}_{2}^{-}-\mathrm{N} 、 \mathrm{DRP}$ 浓度采用 Skalar 流动注射光度法测定. $\mathrm{DOC}$ 浓度采 用岛津 TOC 仪测定. 
表 1 调查水体 $1988-1992$ 年的水文形态特征 ${ }^{[4]}$

Tab.1 Hydro-morphological properties of investigated water during 1988 to 1992

\begin{tabular}{|c|c|c|c|c|c|c|c|}
\hline 序号 & 水体名称 & $\begin{array}{c}\text { 面积/ } \\
\mathrm{km}^{2}\end{array}$ & $\begin{array}{c}\text { 流域面积/ } \\
\mathrm{km}^{2}\end{array}$ & $\begin{array}{c}\text { 水量/ } \\
\left(\times 10^{8} \mathrm{~m}^{3}\right)\end{array}$ & $\begin{array}{c}\text { 平均水深/ } \\
\mathrm{m}\end{array}$ & 补给系数 & $\begin{array}{c}\text { 降雨量 } \\
\text { mm }\end{array}$ \\
\hline 1 & 长湖 & 129.10 & 2265.0 & 2.45 & 1.90 & 17.5 & 1160.0 \\
\hline 2 & 大通湖 & 114.20 & - & 3.30 & 2.89 & - & 1237.7 \\
\hline 3 & 洞庭湖 & 2432.50 & 257000.0 & 155.44 & 6.39 & 105.7 & 1305.0 \\
\hline 4 & 岳阳南湖 * & 11.83 & 150.0 & 0.65 & 5.40 & 12.7 & 1469.0 \\
\hline 5 & 洪湖 & 344.40 & 10352.0 & 6.58 & 1.91 & 30.1 & 1343.3 \\
\hline 6 & 黄盖湖 & 86.00 & 1677.0 & 3.61 & 4.20 & 19.5 & 1469.1 \\
\hline 7 & 武昌东湖 & 33.70 & 187.0 & 0.94 & 2.80 & 5.5 & 1220.0 \\
\hline 8 & 梁子湖 & 304.30 & 3265.0 & 12.65 & 4.16 & 10.7 & 1263.4 \\
\hline 9 & 磁湖 & 10.00 & 62.8 & 0.17 & 1.75 & 6.3 & 1411.0 \\
\hline 10 & 武山湖 & 16.10 & 469.0 & 0.50 & 3.10 & 29.1 & 1330.0 \\
\hline 11 & 柘林水库 ** & 308.00 & 9340.0 & 79.20 & 25.71 & 30.3 & 1570.0 \\
\hline 12 & 鄱阳湖 & 2933.00 & 162000.0 & 149.60 & 5.10 & 55.0 & 1570.0 \\
\hline 13 & 军山湖 & 192.50 & 615.0 & 7.66 & 4.00 & 3.2 & 1587.0 \\
\hline 14 & 珠湖 & 80.80 & - & 4.62 & 5.72 & - & 1570.7 \\
\hline 15 & 龙感湖 & 316.20 & 5511.0 & 11.96 & 3.78 & 17.4 & 1291.3 \\
\hline 16 & 黄大湖 & 299.20 & - & 11.79 & 3.94 & - & 1291.3 \\
\hline 17 & 花凉亭水库 $* *$ & 52.60 & 1870.0 & 23.98 & 45.6 & 35.6 & 1368.4 \\
\hline 18 & 武昌湖 & 100.50 & 1083.7 & 3.45 & 3.43 & 10.8 & 1299.6 \\
\hline 19 & 升金湖 & 78.48 & 1554.0 & 0.99 & 1.26 & 19.8 & 1554.4 \\
\hline 20 & 菜子湖 & 172.10 & 3234.0 & 2.87 & 1.67 & 18.8 & 1241.3 \\
\hline 21 & 巢湖 & 769.55 & 9258.0 & 20.70 & 2.69 & 12.0 & 995.7 \\
\hline 22 & 陈村水库 $* *$ & 88.60 & 2722.0 & 24.75 & 40.00 & 30.7 & 1553.3 \\
\hline 23 & 石臼湖 & 210.40 & 18600.0 & 8.58 & 4.08 & 88.4 & 1174.0 \\
\hline 24 & 滆湖 & 146.50 & - & 1.74 & 1.19 & - & 1010.0 \\
\hline 25 & 太湖 & 2425.00 & 36895.0 & 51.40 & 2.12 & 15 & 1084.0 \\
\hline 26 & 阳澄湖 & 119.04 & - & 1.67 & 1.40 & - & 1033.0 \\
\hline 27 & 淀山湖 & 63.70 & 2265.0 & 1.59 & 2.50 & 35.6 & 1037.7 \\
\hline
\end{tabular}

注: “一”过水性湖泊, 该值未得; * : 数据来源于杨春平等 ${ }^{[17-18]}$; ** : 数据来源于网上公开资料.

\section{3 数据分析与统计}

各湖泊水质参数的平均值采用所有点位测定的数学平均值. 湖泊富营养化评价采用中国环境监测总站 2001 年发布的“湖泊 (水库) 富营养化评价方法及分级技术规定” (总站生字 [2001] 090 号) 计算湖泊富营养 化指数 $(T L I)$, 计算采用 Chl.a、TP、TN、SD、COD ${ }_{\mathrm{Mn}}$ 五参数法, 计算综合富营养化指数时各因子的相应贡献权 重分别为 $0.267 、 0.188 、 0.179 、 0.183 、 0.183$.

\section{2 结果}

\section{1 春、夏季湖泊水质特征}

调查结果表明, 长江中下游地区湖泊富营养化问题依然严重. 春、夏季是湖泊富营养化的关键季节, 是 评估湖泊富营养化状况的主要时段. 本次调查的湖泊春、夏季水质状况如表 2 . 从表中可以看出, 不包括 3 个 水库, 24 个湖泊春、夏季 284 个样品的 TP、DTP、TN、DTN、 $\mathrm{NH}_{3}-\mathrm{N} 、 \mathrm{NO}_{3}^{-}-\mathrm{N} 、 \mathrm{NO}_{2}^{-}-\mathrm{N} 、 \mathrm{DRP} 、 \mathrm{COD}_{\mathrm{Mn}} 、 \mathrm{Chl}$. a 、 $\mathrm{SD}$ 、 Cond $、 S S 、 D O C$ 的平均值分别为 $0.130 \pm 0.144 \mathrm{mg} / \mathrm{L} 、 0.058 \pm 0.085 \mathrm{mg} / \mathrm{L} 、 1.68 \pm 1.32 \mathrm{mg} / \mathrm{L} 、 1.09 \pm 0.80 \mathrm{mg} / \mathrm{L} 、$ $0.123 \pm 0.215 \mathrm{mg} / \mathrm{L} 、 0.550 \pm 0.620 \mathrm{mg} / \mathrm{L} 、 0.028 \pm 0.045 \mathrm{mg} / \mathrm{L} 、 0.034 \pm 0.085 \mathrm{mg} / \mathrm{L} 、 4.81 \pm 1.93 \mathrm{mg} / \mathrm{L} 、 55.8 \pm 192.2$ $\mu \mathrm{g} / \mathrm{L} 、 56 \pm 40 \mathrm{~cm} 、 339 \pm 187 \mu \mathrm{S} / \mathrm{cm} 、 31.68 \pm 33.52 \mathrm{mg} / \mathrm{L}$ 及 $2.98 \pm 1.06 \mathrm{mg} / \mathrm{L}$. 其中, DTP 平均占 $\mathrm{TP}$ 的 $45 \%$, DRP 
平均占 DTP 的 $59 \%$; DTN 平均占 $\mathrm{TN}$ 的 $65 \%$, 离子态氮 $\left(\mathrm{NO}_{3}^{-}-\mathrm{N} 、 \mathrm{NO}_{2}^{-}-\mathrm{N} 、 \mathrm{NH}_{3}-\mathrm{N}\right.$ 之和) 平均占 DTN 的 $76 \%$, DOC 平均占 $\mathrm{COD}_{\mathrm{Mn}}$ 的 $62 \%$.

TP、Chl.a 是长江中下游地区富营养化贡献因子中最为突出的 2 个水质指标. 对照地表水环境质量标准 (GB 3838-2002), 以 TP 为评判依据, 调查的 27 个水体中, 春、夏季平均值达到 II 类水质标准 $(\leqslant 0.025 \mathrm{mg} / \mathrm{L})$ 的只有陈村水库 1 个水体, 达到 III类水质标准的则有花凉亭水库、柘林水库、鄱阳湖、石臼湖、军山湖、珠湖、 梁子湖 7 个水体. IV 类水体湖泊有 8 个, $\mathrm{V}$ 类水体湖泊 7 个, 劣 $\mathrm{V}$ 类水体湖泊有 4 个, 分别为大通湖、武山 湖、滆湖、巢湖, 其春、夏季水体 TP 平均值均超过了 $0.2 \mathrm{mg} / \mathrm{L}$. 当然, 由于本调查采用的湖泊生态系统观测方 案中测定的是水体中所有的溶解态和颗粒态磷, 包括浮游植物颗粒物生物体内的磷, 其结果受浮游藻类生 物量及蓝藻水华的影响较大. 但是, 这也反映出长江中下游湖泊中磷的水平在藻类生长季节普遍较高的 现状.

表 2 调查水体的 2018 年春、夏季主要水质参数均值

Tab.2 Mean value of major water parameters in spring and summer of investigated water in 2018

\begin{tabular}{|c|c|c|c|c|c|c|c|c|c|c|c|}
\hline 水体 & $\mathrm{TP}$ & DTP & $\mathrm{TN}$ & DTN & $\mathrm{NH}_{3}-\mathrm{N}$ & $\mathrm{COD}_{\mathrm{Mn}}$ & Chl.a & $\mathrm{SD}$ & Cond & SS & DOC \\
\hline 长湖 & 0.095 & 0.034 & 1.59 & 1.03 & 0.047 & 5.49 & 68.5 & 60 & 356 & 18.32 & 3.09 \\
\hline 大通湖 & 0.399 & 0.359 & 1.14 & 0.89 & 0.113 & 4.50 & 7.7 & 68 & 364 & 20.35 & 3.65 \\
\hline 洞庭湖 & 0.090 & 0.058 & 1.94 & 1.76 & 0.068 & 2.37 & 6.0 & 54 & 262 & 27.39 & 1.41 \\
\hline 岳阳南湖 & 0.134 & 0.062 & 1.83 & 1.21 & 0.112 & 4.99 & 64.9 & 53 & 267 & 16.36 & 2.94 \\
\hline 洪湖 & 0.104 & 0.043 & 1.46 & 0.95 & 0.197 & 7.11 & 53.8 & 57 & 362 & 17.77 & 3.86 \\
\hline 黄盖湖 & 0.095 & 0.028 & 1.58 & 0.91 & 0.059 & 5.84 & 75.0 & 46 & 344 & 18.22 & 3.37 \\
\hline 武昌东湖 & 0.083 & 0.033 & 0.73 & 0.44 & 0.016 & 4.85 & 37.9 & 64 & 379 & 12.97 & 3.35 \\
\hline 梁子湖 & 0.049 & 0.018 & 0.67 & 0.41 & 0.065 & 3.76 & 21.8 & 110 & 161 & 7.56 & 2.43 \\
\hline 磁湖 & 0.106 & 0.036 & 1.14 & 0.64 & 0.078 & 5.04 & 36.5 & 45 & 425 & 15.98 & 3.09 \\
\hline 武山湖 & 0.387 & 0.202 & 1.88 & 0.69 & 0.082 & 4.92 & 129.2 & 27 & 258 & 47.18 & 3.80 \\
\hline 柘林水库 & 0.039 & 0.014 & 1.11 & 0.73 & 0.016 & 3.28 & 3.6 & 381 & 98 & 3.72 & 1.37 \\
\hline 鄱阳湖 & 0.050 & 0.033 & 1.65 & 1.46 & 0.142 & 3.28 & 16.2 & 67 & 133 & 29.57 & 1.90 \\
\hline 军山湖 & 0.028 & 0.018 & 0.59 & 0.50 & 0.024 & 4.11 & 10.3 & 138 & 435 & 4.55 & 1.77 \\
\hline 珠湖 & 0.027 & 0.017 & 0.47 & 0.32 & 0.020 & 3.43 & 4.2 & 147 & 385 & 5.67 & 1.84 \\
\hline 龙感湖 & 0.129 & 0.044 & 1.19 & 0.56 & 0.017 & 6.68 & 62.4 & 47 & 244 & 13.67 & 4.29 \\
\hline 黄大湖 & 0.055 & 0.024 & 0.72 & 0.46 & 0.013 & 4.39 & 17.8 & 75 & 233 & 15.46 & 3.05 \\
\hline 花凉亭水库 & 0.035 & 0.018 & 0.58 & 0.44 & 0.017 & 2.39 & 4.0 & 317 & 476 & 10.40 & 1.86 \\
\hline 武昌湖 & 0.064 & 0.023 & 0.61 & 0.33 & 0.015 & 3.41 & 18.7 & 33 & 122 & 26.82 & 2.48 \\
\hline 升金湖 & 0.073 & 0.025 & 0.75 & 0.26 & 0.019 & 5.54 & 30.5 & 22 & 192 & 46.77 & 2.13 \\
\hline 菜子湖 & 0.059 & 0.027 & 0.92 & 0.70 & 0.025 & 4.74 & 30.6 & 24 & 194 & 52.89 & 3.44 \\
\hline 巢湖 & 0.261 & 0.069 & 3.39 & 1.51 & 0.132 & 6.98 & 254.4 & 18 & 326 & 63.94 & 3.67 \\
\hline 陈村水库 & 0.013 & 0.010 & 1.34 & 1.22 & 0.022 & 1.73 & 2.3 & 925 & 490 & 3.02 & 1.10 \\
\hline 石臼湖 & 0.041 & 0.023 & 0.98 & 0.60 & 0.274 & 4.23 & 22.3 & 36 & 228 & 22.67 & 2.62 \\
\hline 滆湖 & 0.278 & 0.082 & 2.84 & 1.73 & 0.304 & 7.23 & 89.2 & 25 & 444 & 73.29 & 3.35 \\
\hline 太湖 & 0.148 & 0.040 & 2.62 & 1.67 & 0.338 & 4.83 & 44.4 & 26 & 574 & 60.10 & 3.59 \\
\hline 阳澄湖 & 0.121 & 0.043 & 1.40 & 1.04 & 0.094 & 4.14 & 31.0 & 50 & 528 & 45.73 & 3.27 \\
\hline 淀山湖 & 0.141 & 0.076 & 2.16 & 1.73 & 0.131 & 3.83 & 25.4 & 56 & 629 & 18.01 & 3.70 \\
\hline
\end{tabular}

注: Cond 的单位为 $\mu \mathrm{S} / \mathrm{cm}, \mathrm{SD}$ 的单位为 $\mathrm{cm}, \mathrm{Chl} . \mathrm{a}$ 的单位为 $\mu \mathrm{g} / \mathrm{L}$, 其余参数的单位为 $\mathrm{mg} / \mathrm{L}$.

Chl.a 浓度水平是表征湖泊富营养化状态的核心指标. 按照湖泊 (水库) 富营养化评价方法及分级技术 规定, 以 Chl.a 单项指标划分, 当 Chl.a 浓度超过 $10 \mu \mathrm{g} / \mathrm{L}$ 时, 湖库即可认为处于富营养水平. 依此标准, 春、 夏季水体仍能处于非富营养状态的只有 6 个,包括 3 个大型深水水库. 而 Chl. a 春、夏季平均值超过 $50 \mu \mathrm{g} / \mathrm{L}$ 的水体有 8 个, 最高的为巢湖, Chl. a 平均值达到 $254.4 \mu \mathrm{g} / \mathrm{L}$, 这与调查期间巢湖的蓝藻水华问题较为严重有 关, 特别是在西巢湖的北部靠近南淝河人湖河口附近, 调查期间能看到水色偏黑, 水面能闻到类似城市河道 
的气味, 同时水体的 TP 指标显著偏高.

长江中下游地区湖泊的富营养化状况显著高于水库. 采用 5 参数计算所得的各水体富营养化指数可 知, 3 个水库基本处于或接近贫营养水平 (图 2). 而 24 个湖泊当中, 绝大多数处于富营养水平, 只有洞庭湖、 梁子湖、鄱阳湖、军山湖、珠湖、黄大湖、武昌湖、石臼湖 8 个湖泊达到或接近中营养水平,其余湖泊均处于富 营养水平. 巢湖、滆湖、武山湖甚至达到重富营养水平. 就水库本身而言,一般春季的富营养化指数反而超过 夏季, 特别是柘林水库, 春季处于中营养水平, 夏季则为贫营养. 这与水库的水体温度分层形成及其伴随的 水库营养盐自净能力增强有关. 调查的 3 个水库水深较大, $4-5$ 月是温跃层形成初期, 上下混合作用大,水 质有一定的波动. 而夏季高温期间, 温跃层稳定, 水层上下不交换, 上层的生长层营养盐被藻类大量吸收, 并 随颗粒物沉降到底层, 上层水体营养盐浓度极低.

区域差异性上看, 大城市、人口密度等流域人口活动情况对湖泊富营养化状态有明显影响, 比如巢湖、 太湖等平原经济发展热点区域的 $T L I$ 也更高, 6 个湖泊的 $T L I$ 平均值为 62 . 没有中心城市的鄱阳湖一华阳湖 群中 8 个湖泊富营养化程度相对较低, $T L I$ 平均值为 51 . 而洞庭湖一江汉湖区的 10 个湖泊 $T L I$ 平均值为 57 , 该区域包括了武汉、岳阳、黄石等大型城市,但密度不及东部太湖和巢湖地区.

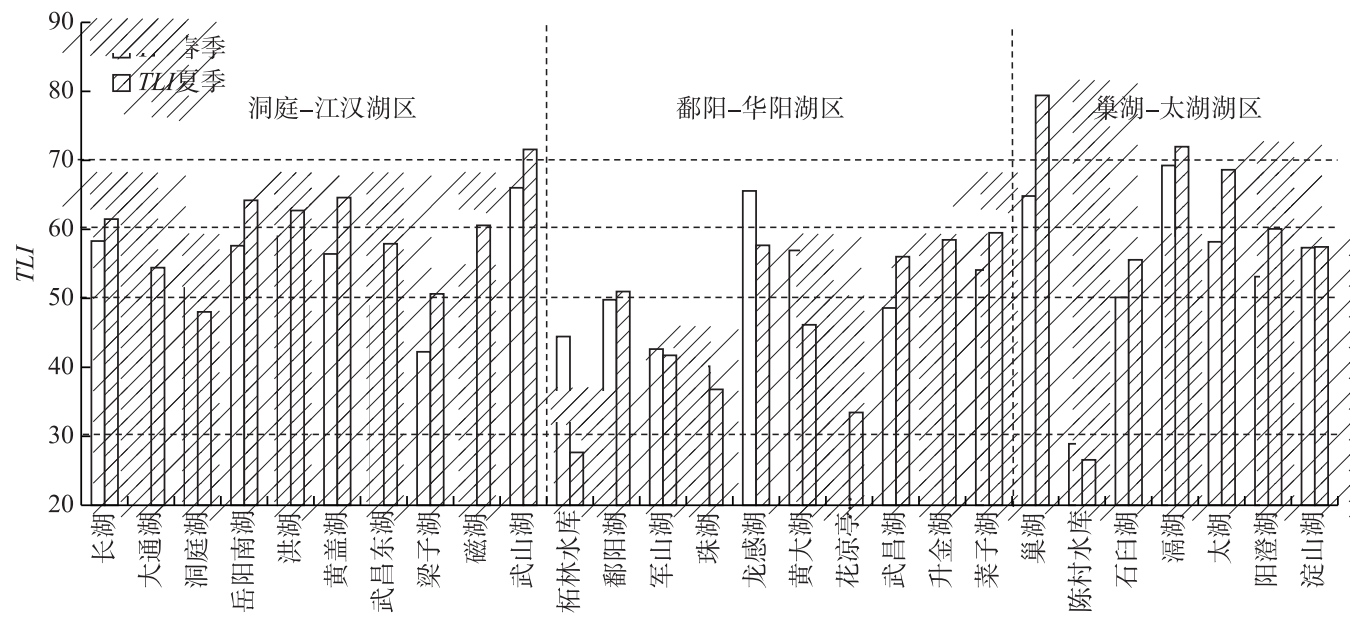

图 2 长江中下游调查湖泊和水库春、夏季富营养化指数

Fig.2 Trophic level index ( $T L I)$ of investigated lakes and reservoirs in spring and summer in the middle and lower reaches of Yangtze River

\section{2 典型湖泊水质的四季变化}

太湖、巢湖、滆湖、鄱阳湖、洪湖、洞庭湖和柘林水库秋、冬、春、夏四季水体主要水质指标变化如图 3. 从 图中可以看出,不同类型湖泊、不同指标的季节变化并不相同.

就 SD 而言, 深水水库柘林水库 4 个季节都显著高于 6 个湖泊, 四季平均值为 $426 \mathrm{~cm}$, 最差为春季, 为 $355 \mathrm{~cm}$. 中游的湖泊显著高于下游: 鄱阳湖、洞庭湖、洪湖的四季 SD 均值分别为 $56 、 48 、 65 \mathrm{~cm}$, 而下游的巢 湖、滆湖、太湖的 SD 四季均值分别为 $20 、 26 、 33 \mathrm{~cm}$.

两大通江湖泊与下游湖泊的 TP 浓度季节变化特征也明显不同: 鄱阳湖、洞庭湖的冬季水体 TP 浓度最 高. 这是由于通江湖泊冬季的来水量下降, 对城市污水等流域排放的污染物稀释降解能力下降, 进人湖泊水 体中的 TP 滞留时间大大增加所致. 而下游的巢湖、滆湖、太湖则夏秋季节水体 TP 浓度明显高于冬、春季, 夏、秋季水体旺盛的浮游植物生长可能是水体 $\mathrm{TP}$ 的重要贡献因子. 水草植被丰富的洪湖和接近贫营养的柘 林水库则春季 TP 浓度明显高于其他季节, 与两类水体中硅藻占比较高, 容易在春季形成硅藻生物量高峰, 从而影响水体 TP 浓度有关.

太湖、巢湖、滆湖、鄱阳湖、洪湖夏季水体 Chl.a 浓度都最高, 而滆湖、洪湖的春季水体 Chl. a 浓度也较高. 太湖、滆湖、巢湖、鄱阳湖、洞庭湖的秋季水体 Chl.a 浓度也都表现出较高的水平, 而水草较为丰富的洪湖, 秋 

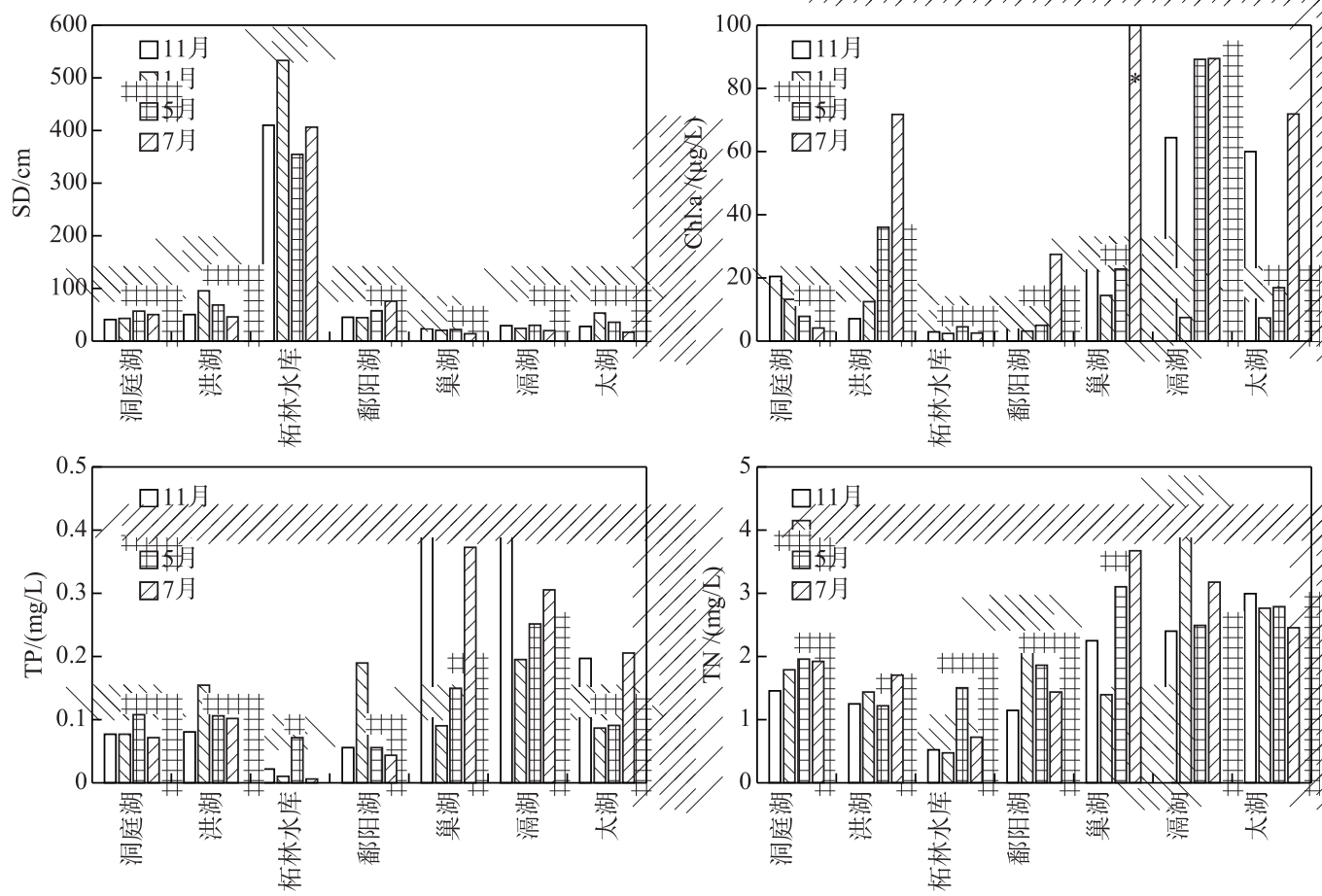

图 3 典型湖泊和水库水质四季变化 ( $*$ : 7 月份巢湖 Chl.a 浓度达到 $486.05 \mu \mathrm{g} / \mathrm{L}$ )

Fig. 3 Seasonal variation of SD,Chl.a,TP and TN in typical lakes and reservoir

季水体 Chl.a 浓度却最低.

7 个水体 TN 浓度的季节变化也不相同, 但总体春季浓度均较高, 其中春季 TN 浓度最高的水体有柘林 水库和洞庭湖. 冬季 TN 浓度最高的是鄱阳湖和滆湖. 秋季 TN 出现峰值的只有太湖. 而夏季 TN 出现峰值的 有巢湖和洪湖.

\section{3 近 30 年来主要水质指标的变化特征}

对《中国湖泊志》所列的 1988-1992 年调查水质数据(代表年以 1988 表示)、2008 年前后第二次中国湖 泊水量水质调查数据 (代表年以 2008 计) 及本次调查数据 (代表年以 2018 计) 的数据库中, 具有共同数据的 16 个湖泊 $T L I 、 \mathrm{SD} 、 \mathrm{TP} 、 \mathrm{TN} 、 \mathrm{COD}_{\mathrm{Mn}} 、$ Chl. a 进行对比,如图 4.

与 1980s 末相比, 湖泊的富营养化状况发生了显著的变化, 特别是过去水质较好的湖泊, 富营养化提升 更加明显. 从图 $4 \mathrm{a}$ 看, $1980 \mathrm{~s}$ 末 16 个湖泊的 $T L I$ 平均值为 47 , 其中大于 50 的湖泊有 6 个, 只占 16 个湖泊中 的 $37.5 \%$, 巢湖、武昌东湖、太湖、磁湖这些人口密度大的地区、城市湖泊的 $T L I$ 较高. 而 2008 年前后, $T L I$ 平 均值已经到了 54 , 其中富营养化的湖泊达到 10 个, 占 $62.5 \%$, 其中变化最大的是滆湖、龙感湖、磁湖、鄱阳湖 和洪湖, $T L I$ 都增加了 10 以上, 这包括渔业开发强度较大的湖泊, 如滆湖和洪湖, 也包括大型通江湖泊鄱阳 湖,还包括城市湖泊,如磁湖. 此外,太湖的 TLI 增幅也比较大. 2008 年与 1988 年相比, TLI 增加了 9, 与该区 域经济的快速发展、土地利用的快速变化有关系. 2008 年与 1988 年相比, TLI 下降的湖泊有 2 个, 即武汉东 湖和巢湖. 与两个湖泊 $1990 \mathrm{~s}$ 以来持续的治理有关. 本次调查春、夏季节的湖泊 $T L I$ 平均值为 57 , 较 10 年前 又有增高, 其中鄱阳湖和梁子湖仍保持中营养水平, 其余湖泊的春、夏季节均处于富营养化状态. 与 2008 年 相比, $T L I$ 显著增加的湖泊主要是巢湖、龙感湖、菜子湖, $T L I$ 的增幅均超过了 10 , 其中的因素, 可能与巢湖的 快速城市化及龙感湖、菜子湖的养殖发展有关. 此外, 洪湖和长湖的 $T L I$ 增加也比较快, 与 2 个湖泊的湖体渔 业等开发活动有关. 与 2008 年相比, 本次调查有 5 个湖泊 TLI 下降, 降幅由大到小分别为磁湖、武昌东湖、淀 山湖、阳澄湖和鄱阳湖, 与这些湖泊的治理活动有关. 

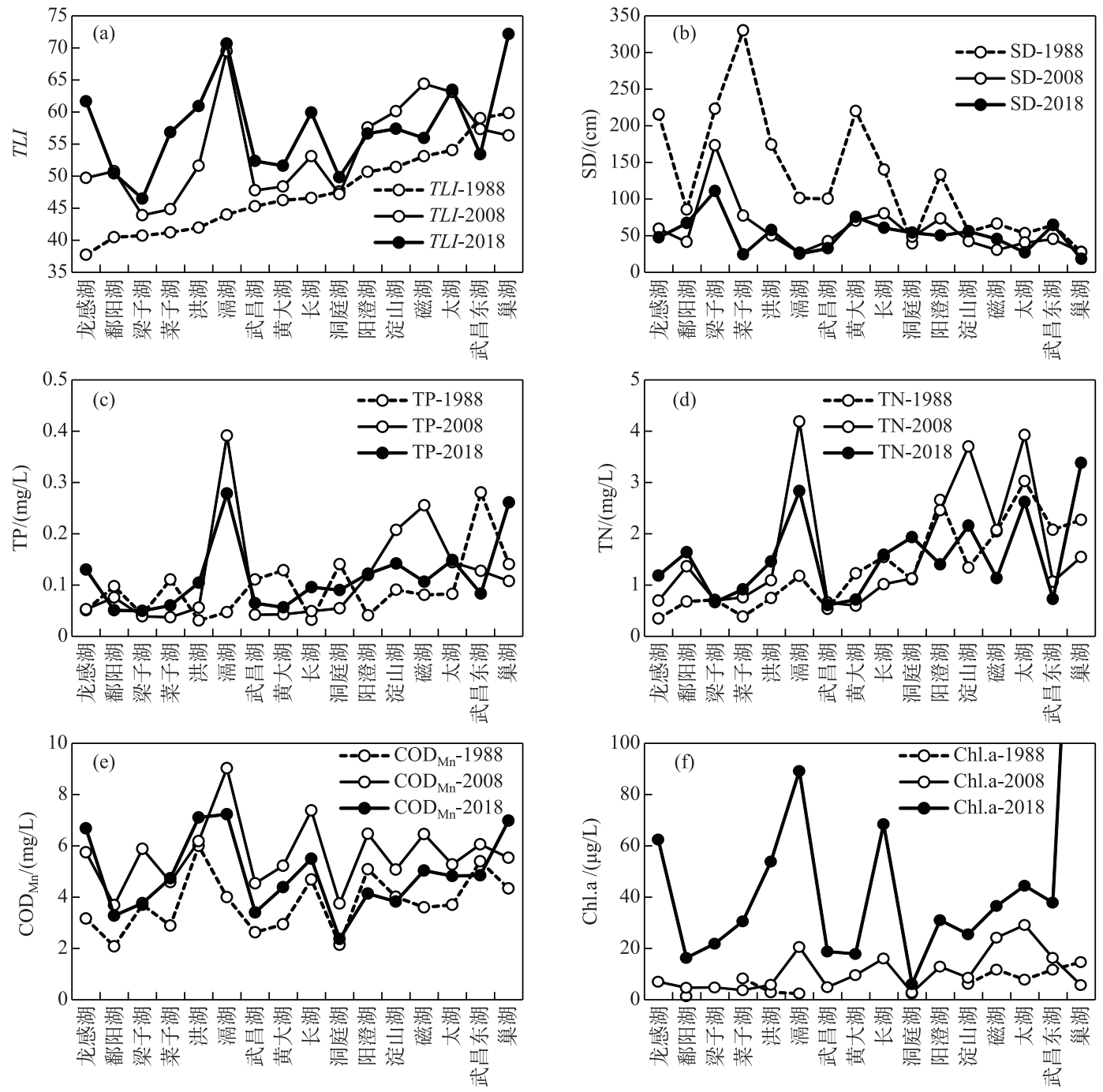

图 4 近 30 年典型湖泊主要水质参数变化 $(*: 7$ 月份巢湖 Chl.a 浓度达到 $486.05 \mu \mathrm{g} / \mathrm{L})$

Fig.4 Change of eutrophication parameters of typical lakes in the past 30 years

从图 4b 至图 $4 \mathrm{f}$ 可以看出, 各个 $T L I$ 相关参数与 $T L I$ 的变化情况并不一致. TN、TP、SD 大致与 $T L I$ 的变 化趋势一致. 3 个时间段 16 个湖泊 $\mathrm{SD}$ 的平均值分别为 $127 、 58 、 51 \mathrm{~cm}$, 下降幅度较大的湖泊包括菜子湖、龙 感湖、黄大湖、洪湖、梁子湖等, 平均 SD 下降超过 $1 \mathrm{~m}$, 而洞庭湖的 SD 反而有所增加. 1980s 末相比, 2008 年 前后总体 TP、TN、COD $\mathrm{Mn}_{\mathrm{Mn}}$ Chl. a 分别增高了 $20 \% 、 23 \% 、 50 \%$ 及 $76 \%$; 从比例来看, 有机质污染的加重幅度高 于氮和磷.

在营养盐变化不大的背景下, 浮游植物生物量急剧增高是近 10 年长江中下游典型湖泊富营养化状况 变化的主要特征. 2018 年与 2008 年相比, TP、TN、COD $、$ 、 Chl. a 均值分别增高了 $3 \%$ 、-8\%、-14\% 及 $240 \%$. Chl.a 是 2018 年相对于 2008 年最大的增量. 这说明近 10 年引起 $T L I$ 增高的关键指标是浮游植物生物量, 而 非营养盐指标, 这种情况与 2017 年太湖蓝藻水华情势加重的情况类似, 也即, 在连续 10 年水体 TN 浓度持 续下降、水体总磷变化不是很大的背景下,2015-2018 年的水体浮游植物叶绿素 a 浓度增加明显 ${ }^{[21]}$. 


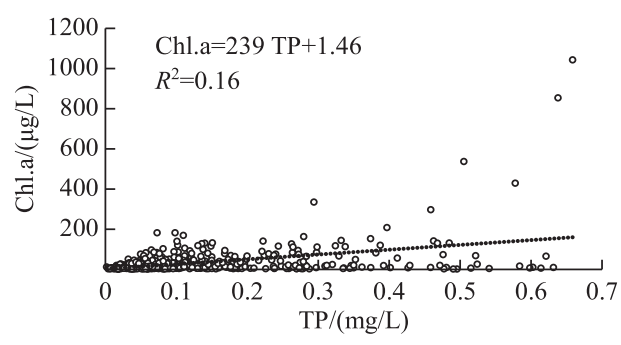

图 5 长江中下游调查湖库水体 Chl.a 浓度与 TP 浓度之间的关系

Fig.5 Relationship between Chl.a and TP concentrations in lakes and reservoirs

in middle and lower reaches of Yangtze River

\section{3 讨论}

\section{1 三十年来非营养盐因素对长江中下游湖泊的富营养 化影响很大}

经典湖沼学认为, 磷、氮是湖泊富营养化风险的重要 促发因素 ${ }^{[22]}$, 特别是磷, 从 1970s 就被北欧、北美等西方 国家认定为湖泊富营养化控制的关键因素 ${ }^{[23-25]}$. 然而, 就 长江中下游湖泊的 3 次调查结果对比看, 磷的变化幅度不 大, 磷似乎不是近 30 年来长江中下游湖泊富营养化状况 加剧的主要推动因子. 从本次调查的数据看, 湖泊 TP 与 Chl. a 的关系并不好 (图 5), 二者的相关系数只有 0.04 $(n=482)$. 这表明, 在长江中下游调查的湖泊中, 磷与藻 类初级生产力的关系不好, 可能不是初级生产力变化的决 定性因素, 或者说, 只是影响初级生产力变化因素之一.

长江中下游地区富营养化变化与营养盐之间关联性较差的原因, 与长江中下游地区湖泊营养盐本底较 高有关. 作为一个洪泛平原湖群, 长江中下游湖泊历史上营养本底就偏高, 使得该区域湖泊本就易于达到较 高的营养水平 ${ }^{[26]}$. 这种高营养本底的自然特征使得该区域许多湖泊以浮游植物生物量为主要标志的富营 养化演替受营养盐变化的影响相对较小. 较为典型的变化是太湖 2005-2017 年的浮游植物 Chl.a 浓度变 化, 在蓝藻水华状况剧烈波动的情况下, 水体与蓝藻生长营养盐供给直接相关的 DTP 浓度始终处于一个平 稳波动状态, 并未发生明显增加或者下降 ${ }^{[21]}$.

生态退化可能是 1988-2008 期间富营养化加剧的直接原因. 从三个阶段的富营养化状况对比可知, 1988-2008 年富营养化加重的主要表征因子是透明度和有机质两个指标, 2008 年的 $T L I(S D)$ 较 1988 年增 高了 $13, T L I\left(\mathrm{COD}_{\mathrm{Mn}}\right)$ 较 1988 年增高了 11, 而 $T L I(\mathrm{TN})$ 只增加了 3, TLI ( TP ) 增加了 1. 尽管由于长江中下游 湖泊水质的季节变化很大, 两次调查的结果具有一定的偶然性, 但是结果仍有较高的可信度. 比如, 就透明 度而言, Feng 等 ${ }^{[27]}$ 采用遥感的方法, 详细分析了长江中下游 50 个典型湖泊 2003-2016 年水体 SD 特征, 总 体 $\mathrm{SD}$ 为 $39 \mathrm{~cm}$, 与 2008 年调查的 16 个湖泊的均值 $(58 \mathrm{~cm}$ ) 比较接近. Hou 等同时也用遥感的方法解译了 $2003-2016$ 年 50 个湖泊的水生植被变化,发现只有鄱阳湖、洞庭湖两个湖泊的水生植被比例显著升高,而 大多数湖泊的水生植被则呈明显下降趋势, 如石臼湖、南渏湖、滆湖、淀山湖、阳澄湖、升金湖、斧头湖等 ${ }^{[28]}$. 水生植被状况对浅水湖泊的底泥再悬浮具有重要的抑制作用, 是保持水体高透明度的关键因子 ${ }^{[29]}$. 因此, 就区域总体湖泊富营养化而言, 透明度的下降、有机质的增加较为明显, 而氮、磷的增量相对较小. 该现象的 原因很可能是草型生态系统退化的因素强于营养盐升高对湖泊初级生产力的影响.

围垦和养殖等直接对湖泊进行经营性开发利用可能是这一阶段湖泊草型生态系统退化、富营养化加剧 的主因. 滆湖、龙感湖、阳澄湖、长湖这些渔场型湖泊的 $T L I$ 都呈现 2008 年较 1988 年相比增加最快的特征 (图 4a). 这一阶段实施的湖泊围网养殖, 在满足渔业生产的同时, 无序开发大量破坏湖泊草型生态系统, 导 致草型生态系统崩溃, 透明度急剧下降, 对湖泊的富营养化具有极大的影响. 如张荣荣等 ${ }^{[30]}$ 遥感解译了洪 湖自然保护区 1974-2017 年景观格局变化,网围养殖密布,滨湖景观破碎度从 1990 年开始急剧增高. 2001 年陈世俭在分析洪湖的生态问题时就指出, 圈养养殖对洪湖的生态资源造成了极大的影响 ${ }^{[31]}$.

江湖阻隔也是 1988-2008 期间长江中下游地区湖泊富营养化加重的一个重要因素. 江湖阻隔的一个 重要原因是湖泊渔业的需要, 当然也是防洪等水资源管理的需求, 但是网围渔业与防洪的共同需求使得江 湖阻隔更为彻底. 网围渔业在特定的历史时期是一项重要的民生工程, 而如今其生态影响则成为必须兼顾 的管理问题. 江湖阻隔通过多种途径影响湖泊的营养水平. 首先, 江湖阻隔大大增加了流域人湖的污染物在 湖体的滞留时间, 放大了流域人湖营养盐负荷的藻类生长促进效应, 使得藻类利用营养盐条件积累到较高 生物量的过程得以实现 ${ }^{[32]}$. 比较极端的例子是三峡大坝的建立, 导致三峡大坝截留了大量的颗粒磷, 而随 着水体流动性下降, 大量的颗粒态转化成溶解性磷释放到水体中, 随大坝放水进人中下游江段 ${ }^{[33]}$. 通江湖 
泊被阻隔之后会发生类似的变化. 其次, 江湖阻隔大大减少了滨湖湿地缓冲带的面积和功能发挥,特别是颗 粒态磷和有机质等对湖泊富营养化有较大影响的物质在缓冲带的沉积, 提高了营养物质在湖泊浮游生态系 统中的迁移效率. 再次, 江湖阻隔还大大降低了湖泊渔业多样性, 比如湖北涨渡湖与长江阻隔之后, 鱼类种 类由约 80 种下降到 52 种, 洄游性和流行性鱼类比重由 $50 \%$ 下降到不足 $30 \%{ }^{[34]}$, 渔业资源的下降缩短或者 阻断了营养盐在初级生产者到消费者、分解者之间的迁移通道, 加快了营养盐在浮游生态系统中的循环速 率. 第四, 江湖阻隔还大大降低了迁徙鸟类的数量, 据 Xia 等对长江两岸 23 个湖泊调查表明, 江湖阻隔的湖 泊迁徙鸟类的数量明显低于通江湖泊 ${ }^{[35]}$, 这会大大降低了鸟类通过捕食和排泄对湖体营养盐的去除通量. 江湖阻隔引发的这些自净能力下降、浮游植物的生产力贡献增加等生态系统变化, 使得在相同的营养盐背 景下,阻隔湖泊的浮游植物 Chl.a 浓度明显高于通江湖泊. Pan 等 ${ }^{[36]}$ 对比分析了洞庭湖、鄱阳湖、石臼湖 3 个 通江湖泊浮游植物 Chl.a 状况发现, 即便是流水区 TP 浓度均值达到 $0.126 \mathrm{mg} / \mathrm{L}$ 、净水区 TP 浓度均值达到 $0.063 \mathrm{mg} / \mathrm{L}$ 的富营养化状态, 水体浮游植物 Chl. a 浓度均值不足 $5 \mu \mathrm{g} / \mathrm{L}$, Chl. a 对 TP 的响应曲线斜率显著低 于江湖阻隔的封闭湖泊.

然而, 城市湖泊的富营养化历程由于受城市污染和高投人治理的双重影响, 对江湖阻隔之后的变化可 能不同. 与 1988 年前后相比, 2008 年城市湖泊磁湖的各项富营养化水质指标都是较差的, 反映出快速城市 化对城市水体的污染影响. 据陈瑞庭等 ${ }^{[37-38]}$ 调查, 1995-2005 年磁湖水体总磷浓度平均值分别为 0.121 、 $0.108 、 0.126 、 0.122 、 0.200 、 0.325 、 0.220 、 0.184 、 0.170 、 0.016 、 0.160 、 0.140 \mathrm{mg} / \mathrm{L}$, 在 2000 年达到最高值, 之后在 不断的治理中开始下降. 2000 年以来, 随着对城市景观需求的提升, 城市湖泊的污染治理普遍得到重视, 其 治理投人大、管理精细, 使近年来城市湖泊的改善幅度明显大于非城市湖泊, 典型的例子是杭州西湖 ${ }^{[39]}$. 因 此, 就城市湖泊而言, 高强度治理投人也成为近 30 年来湖泊富营养化变化的重要因素.

\section{2 长江中下游沿江湖泊生态保护的技术策略}

长江中下游地区是我国淡水湖泊最为集中的地区，也是我国湖泊治理投人最大的地区. 太湖、巢湖、洞 庭湖、鄱阳湖、阳澄湖、淀山湖、滆湖等湖泊在近 20 年来都开展了大规模的污染治理和生态修复. 总体而言, 湖泊的治理效果不理想. 以太湖为例, 在经历了 10 年的高强度治理之后, 湖泊 Chl.a、TP 及蓝藻水华面积和 强度等关键指标的改善效果仍不够理想 ${ }^{[40-42]}$.

依据湖泊的水文和管理, 可以将本次调查的 27 个水体大致分为 6 类: 其中类型 I 为大型水库,包括柘 林水库、花凉亭水库、陈村水库; 类型 II 为通江/半通江湖泊,包括鄱阳湖、洞庭湖、石臼湖、升金湖、菜子湖 5 个水体; 类型 III 为过水性湖泊,包括黄大湖、阳澄湖、淀山湖、珠湖、军山湖 5 个水体; 类型 IV 为渔场型湖 泊，包括洪湖、黄盖湖、长湖、菜子湖、大通湖、武山湖、龙感湖、武昌湖 8 个水体; 类型 $V$ 为大型城市综合纳污 型湖泊, 包括巢湖、太湖、滆湖 3 个湖泊; 类型 VI 为城市湖泊, 包括武昌东湖、磁湖、岳阳南湖 3 个湖泊. 6 个 类型湖泊的 $T L I$ 及其他主要水质参数的变化如图 6 .

从图 6 可以看出,水体的水文管理方式不同、利用类型不同,湖泊的富营养化状况、不同水质指标之间 差异较大. 就 $T L I$ 而言, 大型水库显著低于其他类型, 也即水体深、浅的不同对湖泊富营养化状况影响甚大. 这与荷兰一些科学家提出的挖深湖泊以改善湖泊富营养化状况的思路一致 ${ }^{[43]}$. 然而, 对于大部分通江湖泊 而言, 在湖泊的水位方面并没有太多的调控能力, 在未形成稳定温跃层、改变湖底动力状况情况下的加深湖 泊, 并不能成为一项湖泊富营养化控制的主要技术手段. 但是, 至少可以考虑将局部挖深、捕获浮泥等治理 思路融人到湖泊的综合治理方案中.

通江湖泊、过水性湖泊的 Chl.a 浓度明显低于其他类型湖泊, $T L I$ 值也相对较低 ${ }^{[36]}$. 这表明, 湖泊的水文 节律、换水周期是长江中下游浅水湖泊富营养化状态的重要影响因素之一. 湖泊的流动性不同, 藻类的群落 结构差异很大. 流动性强的湖泊水体藻类对营养盐的生物积累作用大大减弱, 加上整个生态系统完整性的 增加, 可以在较高营养盐本底的条件下维持较好的湖泊水质. 因此, 在技术可行的前提下,水系的连通性、流 动性可以成为解决长江中下游湖泊富营养化问题的一种措施. 比如近年来实施 “六湖连通” 的武汉大东湖治 理方略和工程,对武汉市的东湖等湖泊水体水质改善起到了重要的作用 ${ }^{[4-46]}$. 

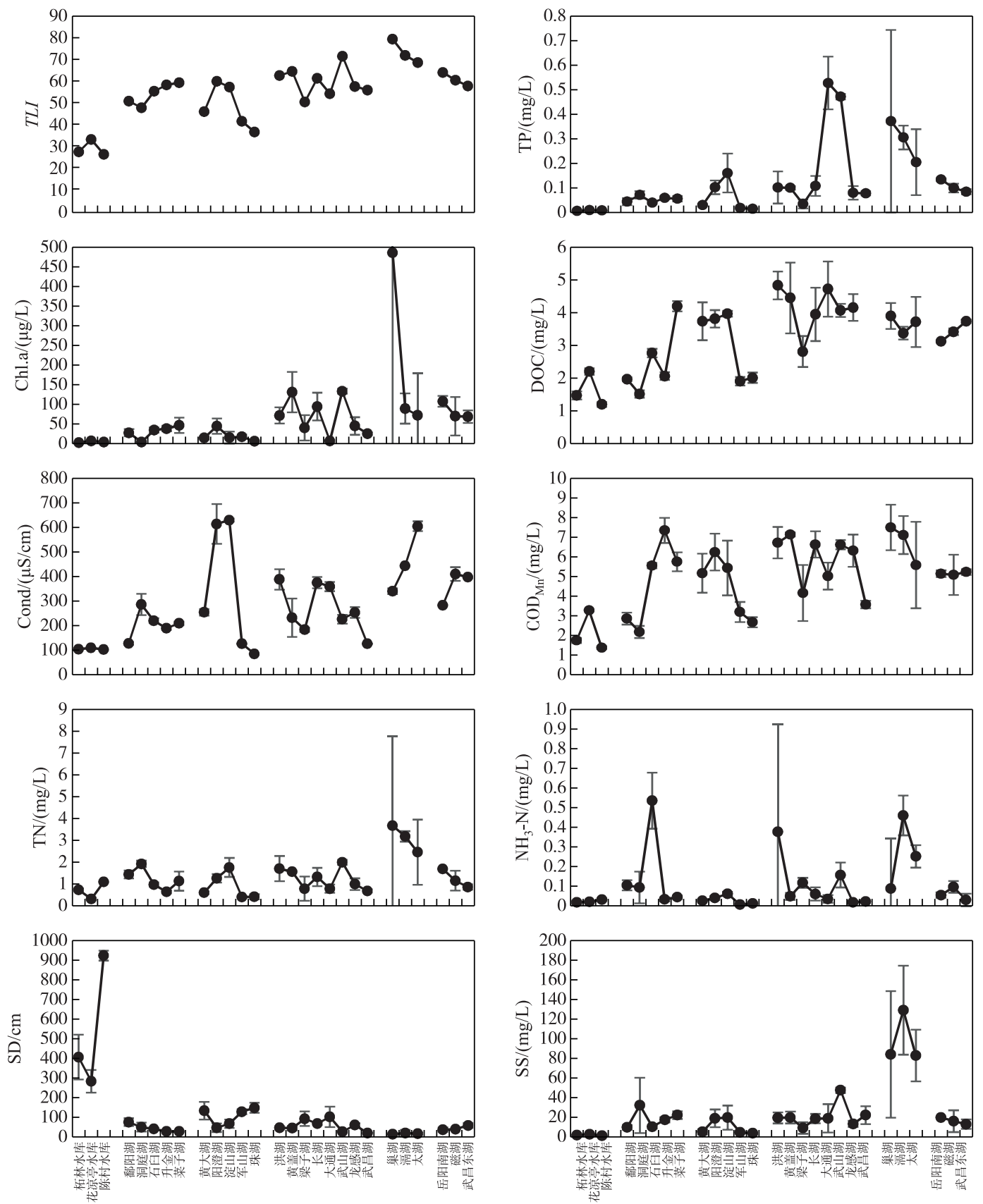

图 6 长江中下游不同类型水体各富营养化相关指标的差异

Fig.6 Difference of trophic state parameters among waterbodies in middle and lower reaches of Yangtze River

本次调查中 Chl.a 浓度极端高值出现在巢湖等大型纳污型湖泊, 这是与巢湖的蓝藻水华问题密切关联 的 (图 6). 当然, 巢湖等区域纳污型湖泊的水体 TP 浓度也最高. Chl.a 与 TP 是相互关联的指标, 较高浓度的 $\mathrm{TP}$ 能够诱发较高的浮游植物生物量. 反过来, 一旦浅水湖泊的春、夏季浮游植物生物量高, 又会促发底泥大 量释放磷, 加剧水体高磷的水质背景, 从而形成恶性循环. 另一方面, 强烈的动力扰动对水体营养盐的大量 补充, 也是这些大型、水面开阔湖泊富营养化易发难治的重要原因. 从图 6 中可以看出, 太湖、巢湖、滆湖的 
水体 SS 显著高于其他类型湖泊. Zhu 等的周年观测和台风过程高频监测都表明, 在没有水草覆盖的水域, 太 湖的底泥再悬浮对水体磷的补给快速而强烈, 总磷的再悬浮周年补给通量是草型湖区的 10 倍以上 ${ }^{[47-48]}$. 此 外, 气候、水文的波动对这些湖泊的富营养化状况、蓝藻水华情势仍有强烈的影响, 比如太湖 2015-2017 年 蓝藻水华暴发的物候学提前了 1 个月 ${ }^{[49]}$, 大大抵消了 10 年的治理成效. 因此, 对太湖、巢湖这种区域纳污型 的大型浅水湖泊而言,富营养化问题严重而顽固. 在治理策略上,需要综合运用流域控源、水文调控、生态修 复和食物链调控等技术, 包括实施更为彻底的控源截污、流域自净体系构建策略等 ${ }^{[50]}$, 而湖体的生态修复, 包括适当的地貌改变以促进草型生态系统的恢复,都是可以考虑的技术措施.

养殖性湖泊的富营养化状态总体较高, 包括大通湖、武山湖等总磷浓度最高的 2 个湖泊. 这表明湖泊的 养殖方式管理必须成为长江中下游浅水湖泊甚至水库富营养化治理和生态修复中重要的工程策略. 鱼是湖 泊生态系统中的顶级物种, 其种群结构和生物量动态变化对藻类生物量和群落结构及其相关联的富营养化 问题产生巨大的影响. 武昌东湖的鲢鳙鱼投放改变了其蓝藻水华情势 ${ }^{[10]}$. 然而, 过量的鲢鯆鱼并不会降低 湖泊的营养盐水平, 甚至会恶化湖泊的水质. 长江中下游地区湖泊渔业大多采取网围养殖的方式. 从该养殖 方式发展之初, 是希望充分利用过水性水体的养分, 在草型湖区设置网围, 利用水草的天然饵料进行养殖, 减少人工养分的投放的经济渔业方式 ${ }^{[51]}$. 在后期发展的网围养殖螃蟹时, 也是开发的“低密度养殖”模 式 ${ }^{[52]}$, 与目前许多湖泊开展的过于追求产量的渔场式、鱼塘式养殖模式并不相同. 从本次调查的情况看, 高 密度、渔场式发展的湖泊, 水质的富营养化状况总体较重. 因此, 从治理的角度看, 湖泊的养殖模式改变, 是 长江中下游许多湖泊生态保护中必须重点考虑的技术途径.

\section{4 结论}

1) 除了水库和个别草型湖泊外, 长江中下游地区湖泊普遍面临呈现富营养状态, 春、夏季水体浮游植物 叶绿素 a 及总磷浓度是最主要的超标因子.

2) 与 1988-1992、2008 年两次调查结果相比, 目前长江中下游湖泊有机质污染加重、浮游植物叶绿素 a 浓度大幅增高, 而氮、磷等营养盐的增量与之相比较小, 水文过程、渔业养殖活动等非营养盐因素对这些湖 泊的富营养化进程起主要作用.

3) 从治理途径看, 增加湖泊的流通性、恢复部分湖泊的自然水文波动节律、优化湖泊渔业管理、提升湖 泊流域营养盐的有效截留能力、实施湖泊生态修复工程是控制长江中下游湖泊富营养化、提升区域湖泊生 态质量的关键.

致谢: 中国科学院南京地理与湖泊研究所高光研究员在调查设计上给与了指导, 施坤、彭凯、董百丽、周蕾、 叶小锐及南京师范大学黄昌春副教授参与了野外调查, 张成英、胡春华、薛静琛、钱荣树、余茂蕾等参与了样 品分析工作,在此一并表示感谢.

\section{5 参考文献}

[ 1 ] Hasler AD. Eutrophication of lakes by domestic drainage. Ecology, 1947, 28(4) : 383-395.

[ 2 ] Edmondson WT, Anderson GC, Peterson DR. Artificial eutrophication of Lake Washington. Limnology and Oceanography, $1956, \mathbf{1}(1): 47-53$.

[ 3 ] Lund JW. Eutrophication. Nature, 1967, 214: 557-558.

[4] Wang SM, Dou HS eds. Records of China lakes. Beijing: Science Press, 1998. [王苏民, 窦鸿身. 中国湖泊志. 北京: 科学出版社, 1998.]

[ 5 ] Ma RH, Yang GS, Duan HT et al. China's lakes at present: Number, area, and spatial distribution. Science China: Earth Science, 2011, 54(2) : 283-289. DOI: 10.1007/s11430-010-4052-6.

[ 6 ] Yang GS, Ma RH, Zhang L et al. Lake status, major problems and protection strategy in China. J Lake Sci, 2010 , 22 (6) : 799-810. DOI: 10.18307/2010.0601. [杨桂山, 马荣华, 张路等. 中国湖泊现状及面临的重大问题与保护策 略. 湖泊科学, 2010, 22(6): 799-810.]

[ 7 ] Wang SM, Xue B, Shen J. The lake environment changes in China and its mechanical explanation. Geological Journal of China Universities, 2009, 15(2) : 141-148. [王苏民, 薛滨, 沈吉等. 我国湖泊环境演变及其成因机制研究现状. 高 
校地质学报, 2009, 15(2): 141-148.]

[ 8 ] Wang SR, Ni ZK, Xi HY. Management process and strategy of lake eutrophication in China. Environmental Protection, 2016, 44(18) : 15-19. [王圣瑞, 倪兆坤, 席海燕. 我国湖泊富营养化治理历程及策略. 环境保护, 2016, 44(18)： 15-19. ]

[ 9 ] Qin BQ. Approaches to mechanisms and control of eutrophication of shallow lakes in the middle and lower reaches of the Yangze River. J Lake Sci, 2002, 14(3) : 193-202. DOI: 10.18307/2002.0301. [秦伯强. 长江中下游浅水湖泊富营养 化发生机制与控制途径初探. 湖泊科学, 2002, 14(3): 193-202.]

[10] Liu JK, Xie P. Unraveling the eninma of the disappearance of water bloom from the East Lake( Lake Donghu) of Wuhan. Resources and Environment in the Yangtze Basin, 1999, 8(3): 312-319. [刘建康, 谢平. 揭开武汉东湖蓝藻水华消失 之谜. 长江流域资源与环境, 1999, 8(3): 312-319.]

[11] Meng RX, Liu ZQ. An evaluation of water pollution and eutrophication of the chaohu lake by means of phytoplankton. Acta Hydrobiologica Sinica , 1988, 12(1) : 13-26. [蒙仁宪, 刘贞秋. 以浮游植物评价巢湖水质污染及富营养化. 水生生 物学报, $1988,12(1): 13-26$.

[12] Xu YF. Influence of comprehensive management of Taihu Basin on water environment. Water Resources Protection, 1989, (1)：41-47. [徐芸芳. 太湖流域综合治理对水环境的影响. 水资源保护, 1989，(1)：41-47.]

[13] Qin BQ, Paerl HW, Brookes JD et al. Why Lake Taihu continues to be plagued with cyanobacterial blooms through 10 years (2007-2017) efforts. Science Bulletin, 2019, 64(6) : 354-356.

[14] Zhang M, Yang Z, Shi XL. Expansion and drivers of cyanobacterial blooms in Lake Taihu. J Lake Sci, 2019, 31 (2) : 336-344. DOI: 10.18307/2019.0203. [张民, 阳振, 史小丽. 太湖蓝藻水华的扩张与驱动因素. 湖泊科学, 2019, 31 (2) : 336-344.]

[15] Gu XH, Zeng QF, Mao ZG et al. Water environment change over the period 2007-2016 and the strategy of fishery improve the water quality of Lake Taihu. J Lake Sci, 2019, 31(2) : 305-318. DOI: 10.18307/2019.0201. [谷孝鸿, 曾庆飞, 毛 志刚等. 太湖 2007-2016 十年水环境演变及”以渔改水”策略探讨. 湖泊科学, 2019, 31(2) : 305-18.]

[16] Huo SL, Xi BD, Yao B et al. Study on the prevention and control of eutrophication in Chinese lakes. Environmental Protection, 2009, (4) : 16-18. [霍守亮, 席北斗, 姚波等. 中国湖泊富营养化防治策略研究. 环境保护, 2009, (4)： 16-18.

[17] Yang CP, Zeng GM, Yuan XZ et al. Study on water quality change trend and protection measures of Nanhu Lake in Yueyang. Chongqing Environmental Science, 1995, 17(2): 23-26. [杨春平, 曾光明, 袁兴中等. 岳阳南湖水质变化趋势 与保护措施研究. 重庆环境科学, 1995, 17(2): 23-26.]

[18] Mei J. The design research of water quality security engineering measures in South Lake of Yueyang[Dissertation]. Changsha: Hunan University, 2013. [ 梅璟. 岳阳南湖水质保障工程措施设计研究 [学位论文]. 长沙: 湖南大学, 2013.]

[19] Qian JL, Fu LM. Determination of total nitrogen and phosphorus in water by persulfate oxidation. Environmental Science, 1987，8(1): 81-84. [ 钱君龙, 府灵敏. 用过硫酸盐氧化法同时测定水中的总氮和总磷. 环境科学，1987，8(1)： 81-84. ]

[20] Chen YW, Chen KN, Hu YH. Discussion on possible error for pytoplankton chlorophyll-a concentration analysis using hotethanol extraction method. J Lake Sci, 2006, 18(5) : 550-552. DOI : 10.18307/2006.0519. [陈宇炜, 陈开宁, 胡耀辉. 浮游植物叶绿素 a 测定的”热乙醇法”及其测定误差的探讨. 湖泊科学, 2006, 18(5) : 550-552.]

[21] Zhu GW, Qin BQ, Zhang YL et al. Variation and driving factors of nutrients and chlorophyll-a concentrations in northern region of Lake Taihu, China, 2005-2017. J Lake Sci, 2018, 30(2) : 279-295. DOI: 10.18307/2018.0201. [朱广伟, 秦伯强, 张运林等. 2005-2017 年北部太湖水体叶绿素 a 和营养盐变化及影响因素. 湖泊科学, 2018, 30(2) : 279-295.]

[22] Xu H, Paerl HW, Qin B et al. Nitrogen and phosphorus inputs control phytoplankton growth in eutrophic Lake Taihu, China. Limnology and Oceanography, 2010, 55(1): 420-432.

[23] Edmondson WT, Anderson GC, Peterson DR. Artificial eutrophication of Lake Washington. Limnology and Oceanography, 1956, 1(1): 47-53.

[24] Weiss CM. Relation of phosphates to eutrophication. Journal of American Water Works Association, 1969, 61 ( 8) : 387-391.

[25] Carpenter SR. Phosphorus control is critical to mitigating eutrophication. Proceedings of National Academy of Science USA, 2008, 105(32) : 11039-11040. 
[26] Qin B, Zhu G. The nutrient forms, cycling and exchange flux in the sediment and overlying water system in lakes from the middle and lower reaches of Yangtze River. Science in China: Series D: Earth Sciences, 2006, 49(S1) : 1-13.

[27] Feng L, Hou X, Zheng Y. Monitoring and understanding the water transparency changes of fifty large lakes on the Yangtze Plain based on long-term MODIS observations. Remote Sensing of Environment, 2019, 221: 675-686.

[28] Hou X, Feng L, Chen X et al. Dynamics of the wetland vegetation in large lakes of the Yangtze Plain in response to both fertilizer consumption and climatic changes. ISPRS Journal of Photogrammetry and Remote Sensing, 2018, 141: 148-160.

[29] Horppila J, Nurminen L. Effects of submerged macrophytes on sediment resuspension and internalphosphorus loading in Lake Hiidenvesi ( southern Finland). Water Research, 2003, 37: 4468-4474.

[30] Zhang YY, Cai XB, Yang C et al. Driving force analysis of landscape pattern changes in Honghu Wetland Nature Reserve in recent 40 years. J Lake Sci, 2019, 31(1) : 171-182. DOI: 10.18307/2019.0116. [张芗芗, 蔡晓斌, 杨超等. 19742017 年洪湖湿地自然保护区景观格局演变及驱动力分析. 湖泊科学, 2019, 31(1) : 171-182.]

[31] Chen SJ. Environmental problems and ecological countermeasures for the Honghulake in Hubei province. Journal of Central China Normal University: Natural Sciences, 2001, 35(1) : 107-110. [ 陈世俭. 洪湖的环境变迁及其生态对策. 华中师 范大学学报: 自然科学版, 2001, 35(1): 107-110.]

[32] Dillon PJ. The phosphorus budget of Cameron lake, Ontario: the importance of flushing rate to the degree of eutrophy of lakes. Limnology and Oceanography, 1975, 20 (1) : 28-39.

[33] Zhou JJ, Zhang M, Li Z. Dams altered Yangtze River phosphorus and restoration countermeasures. J Lake Sci, 2018, 30 (4) : 865-880. DOI: 10.18307/2018.0401. [周建军, 张曼, 李哲. 长江上游水库改变干流磷通量、效应与修复对策. 湖泊科学, 2018, 30(4): 865-880.]

[34] Wang LM, Hu HJ, Wang D. ecological impacts of disconnection from the Yangtze on fish resources in Zhangdu Lake. Resources and Environment in the Yangtze Basin, 2005, 14(3): 287-292. [王利民, 胡慧建, 王丁. 江湖阻隔对涨渡湖区 鱼类资源的生态影响. 长江流域资源与环境, 2005, 14(3): 287-292.]

[35] Xia S, Wang Y, Lei G et al. Restriction of herbivorous waterbird distributions in the middle and lower Yangtze River floodplain in view of hydrological isolation. Wetlands, 2017, 37: 79-88.

[36] Pan BZ, Wang HJ, Liang XM et al. Phytoplankton chlorophyll-a in the Yangtze-connected lakes: present state, influencing factors and empirical relationships. Fresenius Environmental Bulletin, 2009, 18(10): 1894-1900.

[37] Chen RT, Xie ZY. The evaluation of eutropher on Cihu Lake. Journal of Huangshi Polytechnic College, 2004, 20(4) : 61 63. [陈瑞庭, 谢志勇. 磁湖富营养化评价. 黄石高等专科学校学报, 2004, 20(4) : 61-63.]

[38] Zhang LL, Zhao XD, Hu HK et al. Investigation and analysis on the Cihu Lake pollution. Environmental Protection Science, 2008, 34(1): 17-19. [张丽莉, 赵旭德, 胡亨鬼等. 磁湖污染现状调查与分析. 环境保护科学, 2008, 34 (1) : 17-19.]

[39] You AJ, Wu ZY, Han ZC et al. Spatial and temporal distributions and variations of nutrients in the West Lake, Hangzhou, after the implementation of integrated water management program (1985-2013). J Lake Sci, 2015, 27 (3) : 371-377. DOI : $10.18307 / 2015.0301$. [尤爱菊, 吴芝瑛, 韩曾萃等. 引水等综合整治后杭州西湖氮、磷营养盐时空变化 (1985-2013 年). 湖泊科学, 2015, 27(3) : 371-377.]

[40] Qin B, Paerl HW, Brookes J et al. Why Lake Taihu continues to be plagued with cyanobacterial blooms through 10 years (2007-2017) efforts. Science Bulletin, 2019.

[41] Zhang M, Yang Z, Shi XL. Expansion and drivers of cyanobacterial blooms in Lake Taihu. J Lake Sci, 2019, 31(2): 336-344. DOI: 10.18307/2019.0203. [张民, 阳振, 史小丽. 太湖蓝藻水华的扩张与驱动因素. 湖泊科学, 2019, 31 (2) : 336-344.]

[42] Liu JJ, Lu J, Zhu GW et al. Occurrence characteristics of black patch events and their influencing factors in Lake Taihu during 2009 and 2017. J Lake Sci, 2018, 30(5) : 1196-1205. DOI: 10.18307/2018.0503. [刘俊杰, 陆隽, 朱广伟等. 2009-2017 年太湖湖泛发生特征及其影响因素. 湖泊科学, 2018, 30(5) : 1196-1205.]

[43] Penning WE, Uittenbogaard R, Ouboter M et al. Local deepening of large shallow peat lakes: a measure to improve their ecological status. Journal of Limnology, 2010, 69(1) : 126-137.

[44] Yang GL, Lu J, Zhang YJ et al. Connection, circulation, integration and harmony management strategy about water environment of East Lake Water Network Project. China Water Resources, 2013, (9): 24-26. [杨国录, 陆晶, 张艳军等. 浅 议大东湖水环境“联动和谐”治理方略. 中国水利, 2013, (9) : 24-26.] 
[45] Wang Y. Simulation study on water power and water quality of Dadong Lake[ Dissertation]. Beijing: Tsinghua University, 2014. [王玥. 大东湖水系水动力水质模拟研究 [学位论文]. 北京: 清华大学, 2014.]

[46] Zhang S. Study on the ecological environment analysis platform of Dadong Lake water quality based on EFDC Model[ Dissertation]. Wuhan: Huazhong University of Science and Technology, 2017. [张帅. 基于 EFDC 模型的大东湖水质水生 态环境分析平台研究 [学位论文]. 武汉: 华中科技大学, 2017.]

[47] Zhu M, Zhu M, Nurminen L et al. The Influence of macrophytes on sediment resuspension and the effect of associated nutrients in a shallow and large lake (Lake Taihu, China). Plos One, 2015, DOI: 10.1371/journal.pone.0127915.

[48] Zhu M, Paerl HW, Zhu G et al. The role of tropical cyclones in stimulating cyanobacterial (Microcystis spp.) blooms in hypertrophic Lake Taihu, China. Harmful Algae, 2014, 39: 310-321.

[49] Shi K, Zhang Y, Zhang Y et al. Phenology of phytoplankton blooms in a trophic lake observed from long-term MODIS Data. Environmental Science \& Technology, 2019, 53: 2324-2331.

[50] Qin B. Editorial: Lakeeutrophication: Control countermeasures and recycling exploitation. Ecological Engineering, 2009, 35(11) : 1569-1573.

[51] Hu LL, Zhao RK, Zhang XQ et al. Monitoring of water eutrophication after development of pen fishculture in Lake Gehu. Journal of Fisheries of China, 1991, 15(4) : 291-301. [胡莉莉, 赵瑞坤, 张向群等. 滆湖网围养殖后对水体富营养 化的影响. 水产学报, 1991, 15(4): 291-301.]

[52] Wu QL, Chen KN, Hu YH et al. Impacts of pen crab farming on evironment in East Taihu Lake. Agro-Environmental Protection, 2001, 20(6) : 432-434, 442. [ 吴庆龙, 陈开宁, 胡耀辉等. 东太湖河蟹网围养殖的环境效应. 农业环境保 护, 2001, 20(6) : 432-434, 442.] 